\title{
CONCEPTUAL MODEL FOR ASSESSING THE CHANNEL CHANGES UPSTREAM FROM DAM RESERVOIR
}

\author{
MACIEJ LiRO \\ Department of Geomorphology, Jagiellonian University, Cracow, Poland \\ Manuscript received: January 17, 2014 \\ Revised version: February 20, 2014
}

LIRO M., 2014. Model for assessing the channel changes upstream from dam reservoir. Quaestiones Geographicae 33(1), Bogucki Wydawnictwo Naukowe, Poznań, pp. 61-74, 4 figs, 3 tables. DOI 10.2478/quageo-2014-0007, ISSN 0137-477X

AвSTRACT: Most of geomorphological studies related to the impact of dam reservoirs are focused on its effect on the river channels downstream of dams. However, little is known about the evolution of river channels upstream of dams (in backwater areas). In this paper I propose a conceptual model of alluvial channel changes in the backwater. It assumes that three conditions of a channel that may occur in the pre-dam period. These are sediment supply deficit, balance and surplus compared to the river transport capacity. These conditions can be strengthened, stable or weakened. In the post-dam period these conditions is modified by the influence of the dam reservoir, which may affect the trajectory of channel changes, as well as its response and adjustment time in the backwater. The adjustment of channel parameters, in spite of the reservoir operation mode, also depends on the local river, reach characteristics and the magnitude and frequency of floods. Therefore, the use of an appropriate reference reach is inherent in this model. The model suggests that some adverse changes to backwater channels degraded by the regulation can be hampered. The model is based on Lane's balance concept. It may be useful for explaining and predicting channel changes upstream of reservoirs and forming hypotheses in other studies.

KEY WORDS: dam, reservoir, backwater, alluvial, channel adjustment

Address of the corresponding author: Maciej Liro, Department of Geomorphology, Institute of Geography and Spatial Management, Jagiellonian University, Gronostajowa 7, 30-387 Kraków, Poland, e-mail:maciej.liro@uj.edu.pl

\section{Introduction}

At the beginning of the $20^{\text {th }}$ century, there were 427 dams of the height above 15 meters all over the world (ICOLD 1988, after Brandt 2000) and their current number is approximately 50000 (ICOLD 2007, after Kummu et al. 2010). In spite of such a huge number of dams little is known about their impact on the river channels upstream of them. Most contemporary studies and geomorphological models are focused on the impact of dam reservoirs on the changes in channels downstream of them (for review: Petts, Gurnell 2005, Grant 2012). Only a few studies refer to the evolution of river channels upstream of dam reservoirs (Table 1).
Based on the studies of channels downstream of dams, it is known that there is a broad spectrum of adjustments of their parameters to the changes in water flow and sediment transport caused by the construction of reservoirs (Brandt 2000, Petts, Gurnell 2005, Grant 2012). In addition, a large number of local conditions modify the course of adjustment over time and space. Due to the presence of a complex response of river systems to these perturbations, conceptual models are especially useful in predicting channel changes downstream of reservoirs by taking into account the diversity of adjustment types (e.g. Petts 1979, 1980, Brandt 2000, Petts, Gurnell 2005), and they are more easily applicable than empirical models. 
Table 1. The state of research on the channels development upstream dam reservoir

\begin{tabular}{|c|c|c|c|}
\hline Channel parameters & $\begin{array}{l}\text { Short term } \\
\text { changes }\end{array}$ & $\begin{array}{l}\text { Long term } \\
\text { changes }\end{array}$ & Location, reference \\
\hline Channel capacity & $\pm^{7,9}$ & $-9,4$ & \multirow{14}{*}{$\begin{array}{l}1 \text { - Southern USA (Leopold et al. 1964) } \\
2 \text { - Southern USA, Iran, flume studies (Maddock 1966) } \\
3 \text { - Southern USA (Leopold, Bull 1979) } \\
4 \text { - Sheep Creek, USA (Van Haveren et al. 1987) } \\
5 \text { - Illinois, Mississippi River, USA (Bhowmik et al. 1988) } \\
6 \text { - Dunajec River, Poland (Klimek et al. 1990) } \\
7 \text { - Weihe River, China (Xu 1990) } \\
8 \text { - Laohahe River, China (Xu, Shi 1997) } \\
9 \text { - Laohahe and Yangtze River, China (Xu 2001a) } \\
10 \text { - Słupia River, Poland (Florek et al. 2008) } \\
11 \text { - Skawa River, Poland (Książek 2006) } \\
12 \text { - Huron River, USA (Evans et al. 2007) } \\
13 \text { - Yangtze and Jialing River, China (Lu et al. 2010) }\end{array}$} \\
\hline Width and/or depth & $\pm^{7,9}$ & $-4,5,9,13$ & \\
\hline Bed level & $\pm^{7,9}$ & $+3,7,9$ & \\
\hline Slope & $\pm^{7,9}$ & $-1,3,7,9$ & \\
\hline Sinousity & $\pm^{7,9}$ & $+7,8$ & \\
\hline Braiding index & & -8 & \\
\hline \multicolumn{3}{|c|}{ River bed vegetation expansion ${ }^{2,8,10}$} & \\
\hline \multicolumn{3}{|l|}{ Channel form stabilization ${ }^{12}$} & \\
\hline \multicolumn{3}{|c|}{ Higher rate of floodplain deposition $7,8,9$} & \\
\hline \multicolumn{3}{|c|}{ Higher water elevation during floods ${ }^{11}$} & \\
\hline \multicolumn{3}{|c|}{ Buried plants remains in backwaters deposits ${ }^{6}$} & \\
\hline \multicolumn{3}{|c|}{$\begin{array}{l}\text { Reform of channel and floodplain boundary condition } \\
\text { with more cohesive content }{ }^{8}\end{array}$} & \\
\hline \multicolumn{3}{|l|}{ Planform transitions } & \\
\hline \multicolumn{3}{|l|}{ Braided to meander ${ }^{8}$} & \\
\hline
\end{tabular}

There is lack of models assisting in predicting channel changes upstream of dam reservoirs while considering the past and present drainage basin changes and the channel ability to respond to some disturbances having effects that may be concurrent or reverse. Such an approach seems to be justified under increasing human impact, as river response to a reservoir construction may begin at the moment when its channel is not adjusted to previous perturbations. Such a situation can affect adjustment to the perturbation under examination. An example may be a river with several dam reservoirs or one subject to intensive regulation. A sediment deficit and the prevalence of erosion processes may then occur in the channel downstream of a reservoir or in the regulated reach. If an additional reservoir is constructed within this reach, the backwater channel adjustment may be quite different than that without upstream perturbations. Taking such cases into account seems to be justified in connection with the recommendations proposed by Schumm (2005):

1. A broader research perspective by taking into account not only the exact location of investigation, but also upstream and downstream river reaches to provide the representativeness for a study reach.

2. Sensitivity assessment for a river and channel reaches to determine the probability of change occurrence in the research location.
3. Multiple thoughts, i.e. considering various hypotheses to explain a river's behavior, as it may turn out that even the most obvious hypothesis is incorrect.

Taking into account the recommendations given by Schumm (2005) and a particular opportunity to reconstruct and predict channel changes in backwater resulting from precise location of perturbations in time and space in this channel reach, I propose a conceptual model to determine the direction and relative adjustment duration of channel upstream of dam reservoirs. I make the following four assumptions in this model:

1. River systems are characterized by variability in different time and space scales. This results from the adjustment of channel parameters to changes in water flow and sediment supply.

2. Nowadays, the achievement of balance in transport capacity and sediment supply can be hindered or even impossible within a given period of time in river systems subject to intensive human impact. An increasing human impact can cause that the condition of the system can drift towards unbalance.

3. Channel response to current perturbations may begin while a channel is still adjusting to previous perturbations.

4. Both channel response and adjustment may be of various duration and trajectory due to its previous condition and the trajectory of changes. 
In order to better understand the mechanisms of changes to channel parameters within backwater, potential changes in a channel cross-section and planform, in short-term and long-term approaches, are described. In this model particular attention is paid to floods as a factor that modifies the course of channel adjustment.

\section{The current state of research}

The existing studies on river channels upstream of dam reservoirs show changes in channel parameters within the post-dam period, i.e. after the construction of a reservoir (Table 1). These changes proceed upstream of a reservoir, up to the point where the maximum water level curve intersects the channel longitudinal profile curve at the time of reservoir construction (Leopold et al. 1964). However, in the case of gravel bed rivers reservoir impacts can be noticed at some distance upstream (Leopold et al. 1964, Lusby, Hadley 1967).

Changes in channel cross-section (e.g. narrowing, shallowing) proceed faster than those of the longitudinal profile (e.g. slope) and channel planform pattern.

\section{Long-term changes}

In the long-term approach (for dozens of years), the capacity of channels upstream of a reservoir is reduced due to narrowing and/ or shallowing, and channel slope decrease. The width-depth ratio also decreases (Xu 1990, Xu, Shi 1997, Xu 2001a). Due to the increasing content of silt and clay fractions in channel forms, its erosion resistance will increase and the thread can be shifted towards the banks, thus causing channel sinuosity to increase (Xu 2001b). Due to the deposition of fine-grained sediments on the bed forms, its vegetation cover will increase (Maddock 1966, Xu, Shi 1997). The mobility of channel forms will decrease and its dispersion will occur (Evans et al. 2007). In multi-thread channels the number of threads will decrease (Xu, Shi 1997, Xu 2001a, Lu et al. 2010) due to the deposition of sediments inside them and to the succession of vegetation. The floodplain sedimentation rate will increase (Xu 1990, Xu, Shi 1997, Xu 2001b). A channel of lower capacity and slope, as well as of higher sinuosity formed in finer sediments is a result of long-term changes. The channel equilibrium in backwater is understood by $\mathrm{Xu}(1990$, 2001b) as a constant value of channel parameters in a long-term avarage sense.

\section{Short-term changes}

In the short-term approach (for a dozen years), fluctuations in long-term changes of these parameters may occur, for example an increase of the width-depth ratio associated with the prevalence of bank erosion over that of the channel bed or channel shallowing (Xu 1990, 2001a). Such a situation may occur more often at the beginning of the post-dam period. At this time the erosion resistance of channel banks is reduced since the banks are not covered with a sufficiently thick layer of highly cohesive sediments from the reservoir (Xu 2001b). The short-term changes in the channel width and depth will occur particularly during floods. The magnitude of these fluctuations decreases over time due to the intensive deposition of fine-grained sediments from the reservoir, causing the continuous increase of erosion resistance of channel boundary material. Up to this time, in most studies, the changes and values of channel parameters in the post-dam period have been compared with those of the pre-dam period. However, the course of current changes is not explained with reference to the previous and actual trajectory of channel changes. In addition, the existing models of channel evolution within backwaters are based on studies of Chinese rivers of fine-grained beds and high suspensed load (Xu 1990, Xu, Shi 1997, Xu 2001a) and, as shown by Alibert et al. (2011), observations obtained for other types of river channels are not consistent with them.

\section{The biphasity of the processes within the backwater zone}

The processes occurring within the backwater zone may be divided into two phases that differ in their impact on channel adjustment. The course of channel adjustment is a resultant of both of them.

Reservoir impact (Phase I) occurs during the periods of high water levels in the reservoir (base 
level rise). This results in decreasing transport capacity and increasing fine sediment supply in backwater. Transport capacity decreases periodically due to the decrease in the velocity of river flow caused by dam reservoir waters within backwater. Over longer periods of time transport capacity continuously decreases due to the channel slope decrease caused by sediment deposition in the channel. Also, vegetation developing inside the channel on the fine-grained sediments coming from the reservoir and deposited earlier may reduce transport capacity. High water levels in a reservoir can cause bank and slope scouring and supplying material from undercut. The material supplied locally can modify the amount and properties of bed material and channel slope (Leopold, Bull 1979).

No reservoir impact (Phase II) occurs during the periods of lower water levels in the reservoir (base level fall), when the fluvial processes within the backwater zone are undisturbed by the operation of the reservoir. This causes an increase in river transport capacity compared to that of Phase I, and lack of induced fine sediment supply in backwater. Gradual erosion of the part of sediments deposited in Phase I and vegetation growth occur (Maddock 1966). This process may be particularly intensive in elevated bank areas and bedforms. Being another factor that increases deposition at higher water levels, vegetation growth can cause local increases in channel slope (Maddock 1966).

Floods play an important role in Phase II, as they highly intensify the erosion of sediments deposited previously, widen and/or deepen the channel and damage vegetation colonizing the riverbed. The occurrence of floods can decide the occurrence of short-term changes. During floods it is possible that the forms existing and functioning before the reservoir construction will be reactivated, for example the flow can use once again the arms of the channel previously filled with sediments from the reservoir. The changes caused by floods reverse the impacts of a reservoir. This will extend the period of adjustment. Phase II occurs more often over a period of one year. However, as demonstrated by the results of studies on channels in backwater zones (Table 1), over dozens of years after the construction of a dam reservoir channels in backwater may be adjusted to Phase I (e.g. slope decrease, channel narrowing, sinuosity increase).

\section{Lane's balance concept}

The balance concept developed by Lane (1955) has been successfully used in predicting alluvial channel response to perturbations already for almost 60 years (Fig. 1). It indicates proportions between individual components of the fluvial system being in the state of equilibrium:

$$
\mathrm{Q}_{\mathrm{s}} \mathrm{d} \approx \mathrm{Q}_{\mathrm{w}} \mathrm{S}
$$

where: Qs - sediment load, d - sediment size, Qw - water discharge, $\mathrm{S}$ - slope.

This proportion allows to deduce changes that can occur in individual components as a river response to perturbation and approaching the state of equilibrium. For example, if the slope increases due to channel regulation and $\mathrm{Q}_{\mathrm{s}}{ }^{0}$ and $\mathrm{Q}_{\mathrm{w}}{ }^{0}$ are constant, then the river response is an increase of the bed sediments size $\mathrm{d}^{+}$and degradation during the period of adjustment:

$$
\mathrm{Q}_{\mathrm{s}}{ }^{0} \mathrm{~d}^{+} \approx \mathrm{Q}_{\mathrm{w}}{ }^{0} \mathrm{~S}^{+}
$$

Within the backwater zone, water inflow $Q_{w}$ and sediment supply $Q_{s}$ can be considered the same as in the pre-dam period and can be regarded as constant ( $\mathrm{Xu} 2001 \mathrm{~b})$. However, due to the deposition of fine sediments from the reservoir and induced deposition of sediments transported by the river within the backwater zone, the average size of bed sediment ( $\left.\mathrm{d}^{-}\right)$and channel slope $\left(S^{-}\right)$decrease. Aggradation occurs during the period of adjustment:

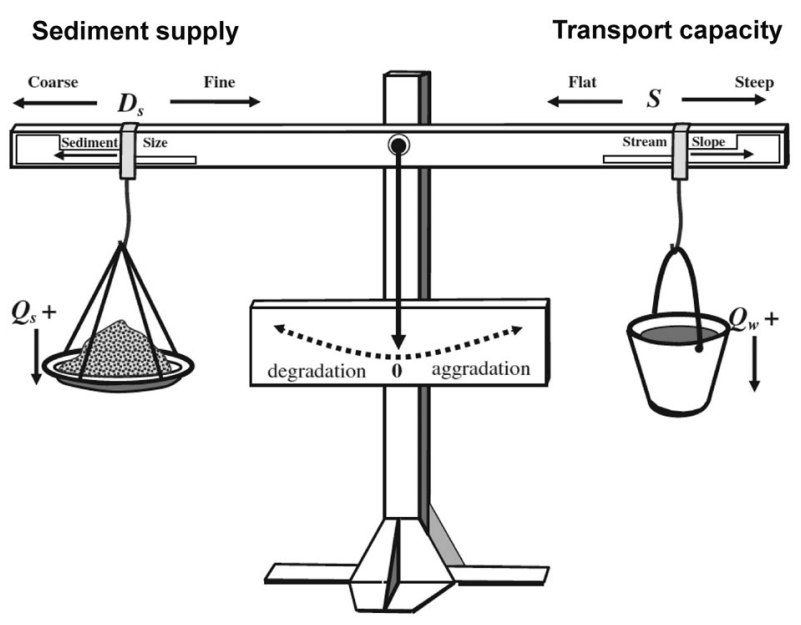

Fig. 1. Presentation of Lane's Balance (after Borland unpublished, from Dust, Wohl 2012, modified) 

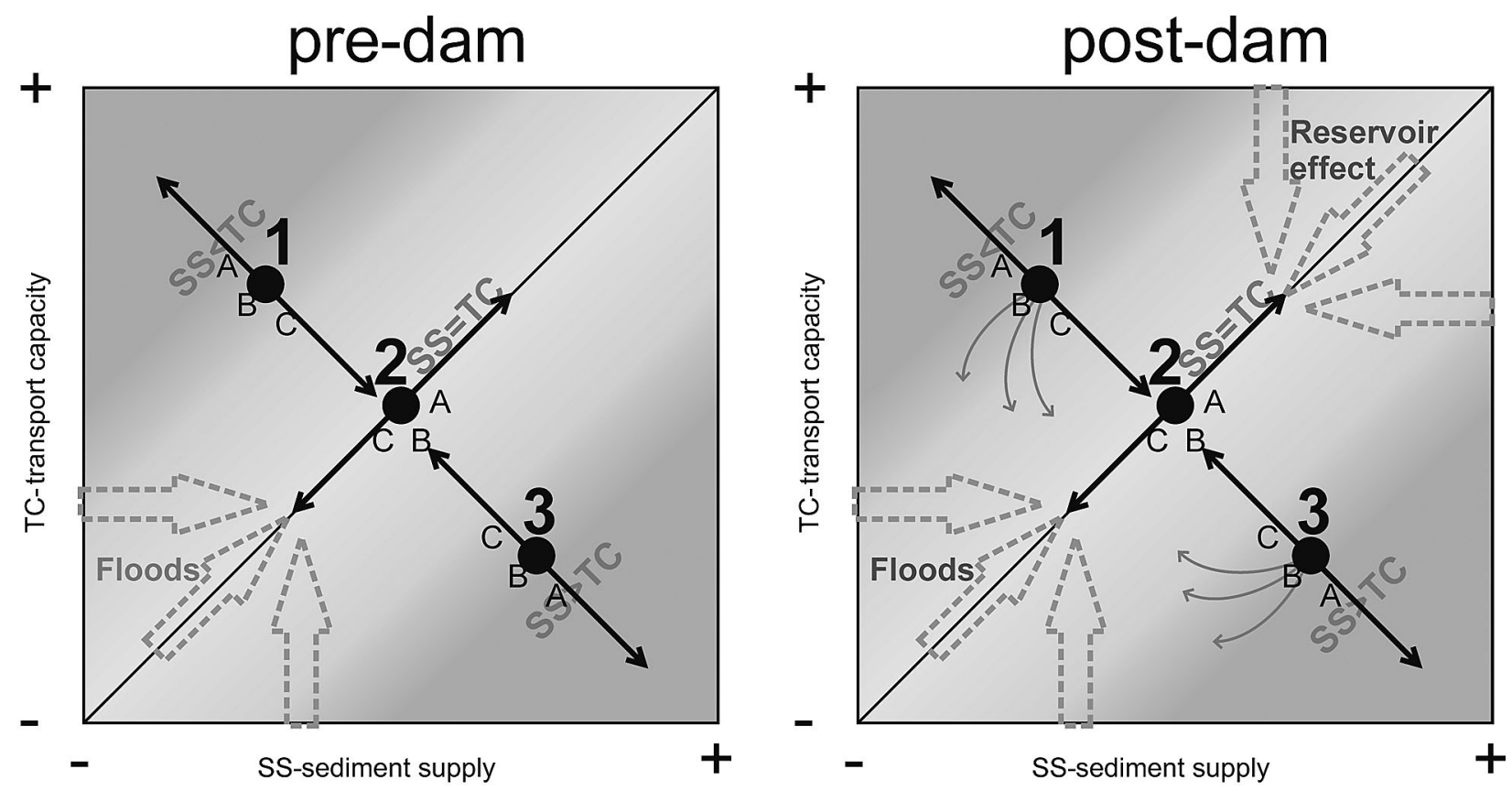

Fig. 2. Schematic representation of trajectory types considered in presented model. Thick dashed arrows represent the impacts of reservoir (TC- $\left.\approx \mathrm{SS}^{-}\right)$and flood (TC+ and/or SS+), while thin arrows represent a hypothetical trajectory of river adjustment towards equilibrium (TC $\approx S S)$ after reservoir construction

$$
\mathrm{Q}_{\mathrm{s}}{ }^{0} \mathrm{~d} \approx \mathrm{Q}_{\mathrm{w}}{ }^{0} \mathrm{~S}^{-}
$$

For reasons of clarity, hereinafter SS - sediment supply is used instead of $Q_{\mathrm{s}} \mathrm{d}$, and TCtransport capacity replace $Q_{w} S$ (Fig. 2). The proportion above will take the following form:

$$
\mathrm{TC}^{-\approx S}-
$$

The direction of response predicted from the Lane's relation is generally consistent with the long-term results of investigations (Table 1). However, it does not allow predicting the period of time for a given adjustment. In the model presented here, the relative times of response and channel adjustment are diversified based on the trajectory of changes from the pre-dam period.

\section{Conceptual model of channel evolution within backwater zones}

Three types of trajectories of channel changes that may occur within the backwater zone are considered. Their course varies depending on the trend in the ratio of river transport capacity (TC) to sediment supply (SS) within the pre-dam period. Three conditions may occur in the channel:
1. deficit (TC $>\mathrm{SS})$,

2. balance $(\mathrm{TC} \approx \mathrm{SS})$, or

3. surplus $(\mathrm{TC}<\mathrm{SS})$ of sediment supply to transport capacity.

In all these conditions, the channel can tend to strenghten (A), remain stable (B) or weaken (C) (Fig. 2).

Within the post-dam period the course of a given trajectory is modified by the influence of the dam reservoir. The effects of the reservoir impact on these trajectories lead in each case to a decrease in transport capacity TC- (through slope decreasing $\mathrm{S}^{-}$) and sediment supply SS- (through decreasing bed sediment size $d^{-}$). Thus, the longterm change in backwater is a simultaneous decrease in transport capacity and sediment supply (sediments in the qualitative meaning).

$$
\mathrm{TC} \approx \mathrm{SS}^{-}
$$

The symbol for proportionality " $\approx$ " between TC and SS indicates that any changes in the quality (d) or amount of sediments $\left(Q_{s}\right)$ are proportional to changes in components $\left(Q_{w^{\prime}} S\right)$ related to transport capacity (TC). However, depending on the earlier channel condition and the trajectory of changes, the time/amount of work done by the river to reach equilibrium $\mathrm{TC} \approx \mathrm{SS}$ in the channel 
must be different. Therefore, I differentiate in the model the relative length of adjustment within backwater in respect of its earlier condition and trajectory of channel changes (Table 2). Based on trajectories from the pre-dam period, long-term changes in channel parameters within the postdam period are deduced using Lane's (1955) relation (Table 2). Cases of the same trajectories within the pre- and post-dam periods are marked, thus indicating possible adjustment acceleration for a given parameter.

The course of adjustments for individual channel parameters is regulated by a wide spectrum of factors (nature and volume of sediments, bank and channel erosional resistance, floods etc.) (Werrity 1997). The effect of floods is presented as flood related short-term changes (Table 3 ).

In order to determine a given trajectory from the model, it is necessary to consider the course of parameters under investigation based on some local conditions present in a specified research location and confront them with an appropriately chosen reference reach. The procedure of model use is presented at the end of the article (see section The application of the model). The model takes into account the fact that changes of some parameters can be unsynchronized with each other and can be compensated by changes of other parame- ters (Leopold, Bull 1979). For instance, in a gravel bed river where a sediment deficit occurred during the pre-dam period (Cases 1) (Table 2) an armoured bed can develop, hindering further erosion during floods within the post-dam period. Such a situation could not occur in a sand bed river (Grant 2012). The effects of the reservoir impact are also presented schematically for river cross-section and planform (Fig. 3).

The presented model and procedure of its application (see section The application of the model) in some sense combine the findings from earlier models those had been successfully used ( $\mathrm{Xu}$ 1990, Xu, Shi 1997, Xu 2001a, b, Phillips 2013).

The case descriptions for the pre-dam period are based mainly on the classification of channel changes downstream of dam reservoirs provided by Brandt (2000). The presented model may be treated as further development of Brandt's work upstream of a dam as well as a new application of Lane's (1955) balance concept.

Cases of type 1 include channels where a sediment deficit occurred during the pre-dam period. They can occur in channels subject to intensive hydrotechnical work (e.g. the impact of upstream reservoirs), regulation and changes of material supply from the river basin due to changes of land use. In such channels reaching equilibrium

Table 2. The conceptual model of long-term channel changes within the backwater zone

\begin{tabular}{|c|c|c|c|c|c|c|c|c|c|c|c|c|c|c|c|c|c|c|}
\hline Pre-dam & \multicolumn{6}{|c|}{ Sediment deficit } & \multicolumn{6}{|c|}{ Sediment balance } & \multicolumn{6}{|c|}{ Sediment surplus } \\
\hline $\begin{array}{l}\text { Case } \\
\text { Pre-dam }\end{array}$ & \multicolumn{2}{|c|}{$\begin{array}{c}1 \mathrm{a} \\
\mathrm{TC}^{+}>\mathrm{SS}^{-}\end{array}$} & \multicolumn{2}{|c|}{$\begin{array}{c}1 \mathrm{~b} \\
\mathrm{TC}^{0}>\mathrm{SS}^{0}\end{array}$} & \multicolumn{2}{|c|}{$\frac{1 \mathrm{c}}{\mathrm{TC}^{->S S^{+}}}$} & \multicolumn{2}{|c|}{$\begin{array}{c}2 \mathrm{a} \\
\mathrm{TC}^{+} \approx \mathrm{SS}^{+}\end{array}$} & \multicolumn{2}{|c|}{$\begin{array}{c}2 \mathrm{~b} \\
\mathrm{TC}^{0} \approx \mathrm{SS}^{0}\end{array}$} & \multicolumn{2}{|c|}{$\begin{array}{c}2 \mathrm{c} \\
\mathrm{TC}^{-} \approx \mathrm{SS}^{-}\end{array}$} & \multicolumn{2}{|c|}{$\begin{array}{c}3 \mathrm{a} \\
\mathrm{TC}^{-}<\mathrm{SS}^{+}\end{array}$} & \multicolumn{2}{|c|}{$\begin{array}{c}3 \mathrm{~b} \\
\mathrm{TC}^{0}<\mathrm{SS}^{0}\end{array}$} & \multicolumn{2}{|c|}{$\begin{array}{c}3 \mathrm{c} \\
\mathrm{TC}^{+}<\mathrm{SS}^{-}\end{array}$} \\
\hline $\begin{array}{l}\text { Channel } \\
\text { parameter }\end{array}$ & pre & post & pre & post & pre & post & pre & post & pre & post & pre & post & pre & post & pre & post & pre & post \\
\hline Capacity & + & - & + & - & - & - & + & - & 0 & - & - & - & - & - & - & - & + & - \\
\hline $\begin{array}{l}\text { Width and/ } \\
\text { or depth }\end{array}$ & $+/-$ & - & $+/-$ & - & $+/-$ & - & + & - & 0 & - & - & - & $+/-$ & - & $+/-$ & - & $+/-$ & - \\
\hline Bed level & - & + & - & + & $-/ 0$ & + & 0 & + & 0 & + & 0 & + & + & + & + & + & $+/ 0$ & + \\
\hline $\begin{array}{l}\text { Bed sedi- } \\
\text { ment size }\end{array}$ & + & - & + & - & $+/ 0$ & - & $0 /+$ & - & 0 & - & $0 /-$ & - & - & - & - & - & $-/ 0$ & - \\
\hline \multicolumn{2}{|c|}{$\begin{array}{l}\text { Relative channel } \\
\text { adjustment dura- } \\
\text { tion }\end{array}$} & \multicolumn{5}{|c|}{ case $1 \mathrm{c}<$ case $1 \mathrm{~b}<$ case $1 \mathrm{a}$} & \multicolumn{6}{|c|}{ case $2 c<$ case $2 b<$ case $2 a$} & \multicolumn{6}{|c|}{$\begin{array}{c}\text { case } 3 a \text {, case } 3 b<\text { case } 3 c ? \\
\text { Depending } \\
\text { on braids development }\end{array}$} \\
\hline
\end{tabular}

Explanations: The direction of changes to channel parameters is diversified, based on sediment supply deficiency, and balance and surplus within the pre-dam period. The duration of adjustment is diversified based on the direction of these states. The direction of the trend of these parameters is a relative value in relation to their value in the pre-dam period. The trends of pre-dam parameters can be still detectable in the reference reach of a river out of backwater. The same tendencies of channel development in the pre- and post-dam periods are marked in grey. 
Table 3. Floods related short-term changes in relation to long-term changes in backwater

\begin{tabular}{|l|c|c|}
\hline \multicolumn{1}{|c|}{ Channel parameters } & $\begin{array}{c}\text { Flood related } \\
\text { short-term } \\
\text { changes }\end{array}$ & $\begin{array}{c}\text { Long-term } \\
\text { changes }\end{array}$ \\
\hline Channel capacity & \pm & - \\
\hline Width and/or depth & \pm & - \\
\hline Bed level & \pm & + \\
\hline Bed sediment size & \pm & - \\
\hline Terraces sedimentation & \pm & + \\
\hline
\end{tabular}

between sediment supply and transport capacity can be locally or temporally impossible, especially in the case of artificial constructions of the channel bed and banks.

\section{Case 1a: TC $^{+}>$SS $^{-}$Strengthening sediment deficit Pre-dam}

In this case erosion processes in the channel prevail over accumulation and bars are removed. Channel capacity increases through deepening and/or widening (Brandt 2000). The amount of material supplied in such a way is too small to compensate for the deficit in sediment supply. In the case of a gravel bed river, armouring can develop in the channel, thus protecting the bed against further erosion (Grant 2012). Depending on the ratio of bank resistance to that of an armoured bed, it can be justified to widen or deepen the channel. Due to increasing transport capacity, a larger amount of erosion of the river bed, banks, and former river terraces will occur. Pools may be eroded. Both deposition and erosion can occur in riffles, depending on the degree of sediment deficiency (Brandt 2000, case 7).

Post-dam

In this case the effects of the impact of reservoirs can include weakened erosion in the channel. This will slow down or hamper channel deepening and widening, and reduce channel capacity. During high water levels in the reservoir, material can accumulate on terraces. Erosion of terraces and/or accumulation can occur during floods. Potentially existing channel bed and bank protection constructions will be covered with sediments and will not have an impact on the bed any more. In longer periods of time, due to aggradation on the channel bed above bed and bank protection constructions, a larger increase of channel sinuosity will be pos-

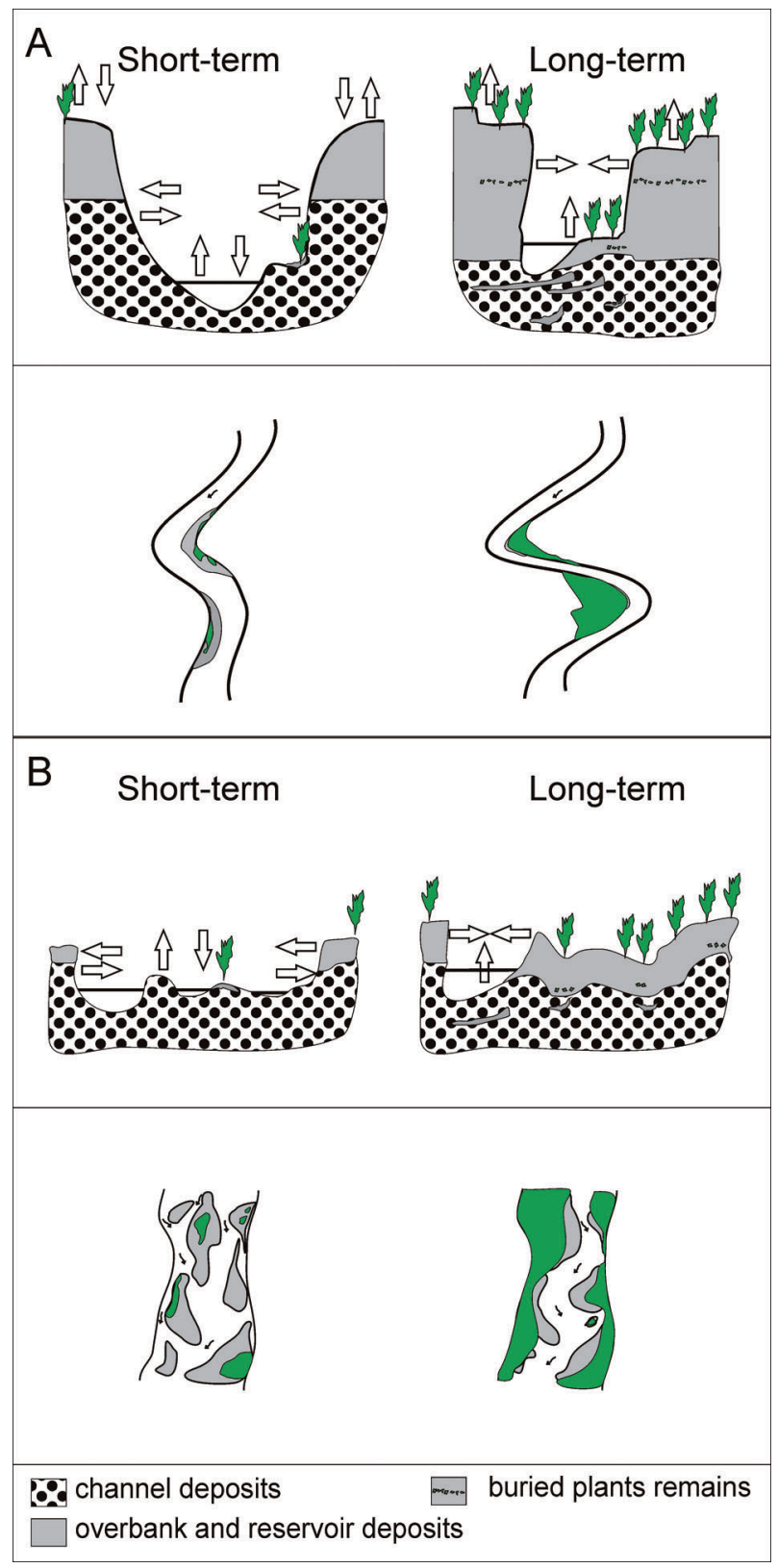

Fig. 3. Potential effects of backwater changes in a channel or in single-thread (A) and multi-thread (B) reaches

sible (Fig. 4). Paradoxically, consequences of such changes indicate that an ecologically disadvantageous condition of the channel resulting from river regulation and hydrotechnical construction development in the pre-dam period can be improved in the backwater reach by processes that favour slope decrease, sinuosity increase and vegetation expansion. Channel adjustment will be longest among all cases of type 1 (Table 2). 


\section{Case 1b: $\mathrm{TC}^{0}>\mathrm{SS}^{0}$ Stable sediment deficit}

Pre-dam

The mechanism of changes will be analogous to that of case 1a but, due to the constant levels of transport capacity and sediment supply, an increase in channel capacity by widening or deepening it will be smaller (Brandt 2000, case 4). Post-dam

The mechanism of changes will be the same as in case 1a (Table 2). Adjustment duration will shorter since sediment deficit does not increase (Table 2, Fig. 2).

\section{Case 1c: TC $>\mathrm{SS}^{+}$Weakening sediment deficit Pre-dam}

Transport capacity decreases and sediment supply increases, thus decreasing the sediment deficit in the channel. Erosion can proceed; however, it will affect only the deeper part of the channel. Channel deepening or widening will depend on relative erodibility between the bed and bank material. In a gravel-bed channel significant degradation may not occur (Kellerhals 1982 after Brandt 2000). The channel parts not used by water flow will be overgrown with vegetation and converted into a floodplain. Deposition may occur downstream of tributaries due to reduced flow competence (Brandt 2000, case 1).

Post-dam

The mechanism of changes is the same as in case 1a. Adjustment, however, will be shorter than that of case $1 b$ (Table 2).

Cases of type 2 show potential channel response and adjustment in channel with balance between transport capacity and material supply.

\section{Case $2 a: \mathrm{TC}^{+} \approx S S^{+}$Stable increase in transport ca- pacity and sediment supply \\ Pre-dam}

In this case a steady increase in transport capacity and material supply takes place. Channel capacity increases by widening and/or deepening it, however, without the prevalence of erosion or accumulation. Pool erosion and deposition in riffles can occur, too (Chorley et al. 1984, Hey 1986 after Brandt 2000). The channel planform pattern will change towards higher flow energies (e.g. meandered into braided one) (Brandt 2000, case 8). As a result of increasing transport capacity and sediment supply, the possibility of deposition on the floodplain and terraces increases.

Post-dam

The mechanism is the same as in case 1a. Due to increased transport capacity and sediment supply, however, adjustment will be the longest of all cases 2 (Table 2).

Case 2b: $T C^{0}=S S^{0}$ Balance between transport capacity and sediment supply

Pre-dam

Pre-dam transport capacity is proportional to sediment supply. Channel capacity oscillated around a constant value appropriate for supplied material transport. There is a balance between erosion and accumulation in the channel and on the floodplain. The channel bed is stable in level due to the balance between aggradation and degradation. Also, channel depth is relatively stable. Bank erosion was compensated by sediment accumulation, thus maintaining almost stable channel width. In the case of diurnal flow fluctuation downstream of a dam, bank erosion without compensatory deposition can occur (Williams, Wolman 1984 after Brandt 2000, case 5).

Post-dam

The mechanism of changes is the same as in case $1 \mathrm{a}$. Since no tendencies to increase the channel size are present within the pre-dam period, channel adjustment will be shorter than in case 2a (Table 2).

\section{Case $2 c: T C^{-} \approx S S^{-}$Stable decrease in transport ca- pacity and sediment supply \\ Pre-dam}

Both transport capacity and sediment supply decrease proportionally. The narrowing and/or shallowing of the channel occur, thus decreasing its capacity. Riffles should not be eroded intensively and an increase in their stability is possible. Deposition in pools increases. There is little probability of the occurrence of an armoured bed. The amount of water flow decreases and non-active channel parts become overgrown with vegetation and converted into floodplains and terraces. Tributary deposition also occurs (Brandt 2000, case 2).

\section{Post-dam}

Due to the impact of the reservoir, the previous tendencies will be additionally deepened. 
Intensified aggradation in the channel and sediment accumulation at channel banks can accelerate its narrowing and channel capacity decrease. In connection with additionally decreased channel capacity, overbank flows can be more frequent. The vegetation on the floodplain can be partially buried under sediments (Fig. 3). Such plant remnants occur in quickly deposited sediments, on channel banks upstream of dam reservoirs (Klimek et al. 1990). The same tendencies in channel evolution in the pre- and post-dam periods can accelerate the channel adjustment to backwater conditions. The acceleration will be the highest among Cases 2 (Table 2). The course of response and adjustment of some channel parameters can be less noticeable, as similar tendencies occurred within the pre-dam period (Fig. 4).

Cases of type 3 represent channels in which there is a surplus of material supply to transport capacity in the pre-dam period. Such situations can occur downstream of dam reservoirs during sediment flushing and when river water is used for irrigation, as well as due to changes in the land use of the drainage basin increasing material supply to the channel (e.g. land use changes).

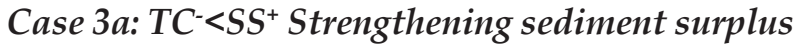
Pre-dam

Due to decreasing transport capacity, the river is more loaded and the amount of water flow impact is smaller. Channel capacity decreases by narrowing and/or shallowing it. It is probable that new threads will be formed and bar deposition will occur (Hoey, Sutherland 1991 after Brandt 2000). Such tendencies occur downstream of flood control reservoirs in China. Sediments deposited within a reservoir during a flood are scoured out after the flood and cause river overloading downstream of a reservoir. The results of fine sediment deposition on/in coarser channel sediments occur particularly downstream of a reservoir (Chien 1985 after Brandt 2000). Terraces can be formed. The channel planform pattern and bedforms can drift both towards more and less active configurations (Brandt 2000, case 3). Post-dam

Adjustment will be similar to that in case $3 \mathrm{~b}$ (Table 2).

\section{Case 3b: $\mathrm{TC}^{0}<S S^{0}$ Stable sediment supply surplus Pre-dam}

The channel decreases its capacity due to narrowing and/or shallowing it. Deposition in riffles

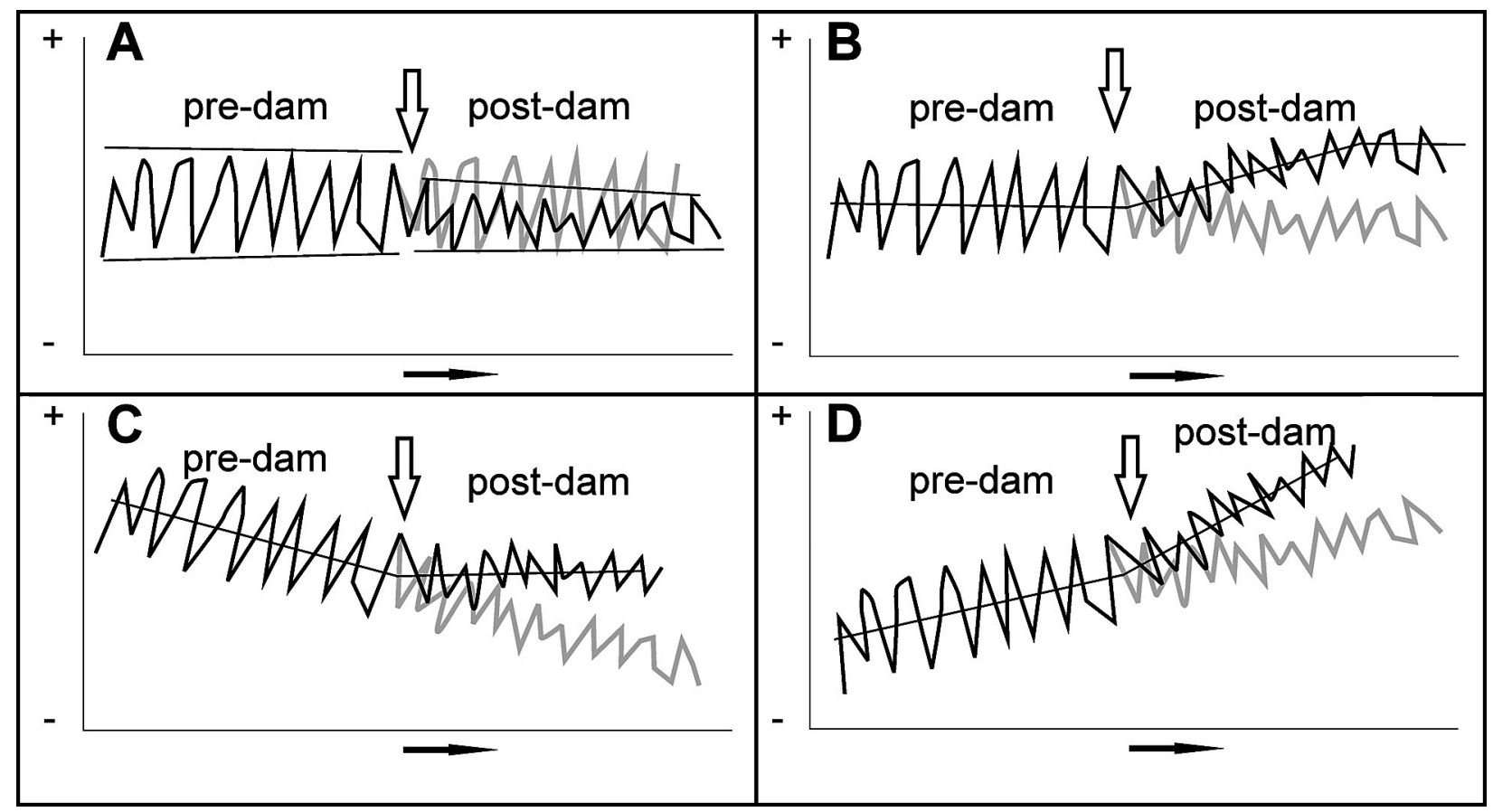

Fig. 4. Hypothetical courses of a given channel parameter in the pre- and post-dam periods. Different response types are visible in respect to previous trajectories of changes. A - change in parameter range. B, C, D - trajectory changes. In grey is noted the course of a parameter in reference reach 
and pools occurs. In the case of rivers of very high concentration of suspension load, the channel initially narrows and then deepens. An overbank flow, flow width increase and slope increase can occur in aggrading rivers, while the bed grain size can decrease. During floods, avulsion may also occur in aggrading channels. Because of reduced channel capacity, the frequency of overbank flows and floodplain deposition will increase. Due to the excess of sediment supply over transport capacity, the channel planform pattern and bedforms turn into more energetic configurations. Such cases occur temporarily downstream of reservoirs during flushing (Brandt 2000, case 6).

Post-dam

The direction of changes is the same as in the previous cases. Adjustment will be similar to that of case 3a (Table 2), and can be shorter in rivers with high suspension load.

\section{Case $3 c$ : TC $^{+}<S S^{-}$Weakening sediment surplus Pre-dam}

Channel capacity can increase. As Brandt (2000) notes, the bed level can rise but such situations are very rare. Deposition occurs in riffles, erosion or deposition in pools are possible, and so is deposition on low terraces. For hyperconcentrated flows in the channel, no deposition should occur. The channel planform pattern and bedforms evolve towards a more active configuration (Brandt 2000, case 9).

Post-dam

In this case there is a higher probability that the remnants of inactive arms of the channel related to the pre-dam period will remain in the relief. They can be re-active during floods. The mechanism of changes is the same as in case 1a. Adjustment will be longer than that of case $3 a, b$ (Table 2).

\section{The course of changes with space and time}

\section{The course of changes in the longitudinal profile of a river}

The maximum water level in a reservoir determines the maximum backwater extent in the longitudinal profile of a river (Leopold et al. 1964). However, the changes will not occur at the same time in the whole backwater area. This results from different frequency of occurrence of water levels of a specified height that cause changes in a specified backwater reach.

\section{The frequency of the reservoir impact on the channel in backwater}

The part of backwater in close proximity to the reservoir will be more often flooded with its water. The distal part of backwater, i.e. higher in the longitudinal profile of a river, the less frequent such a situation. Therefore, any changes described in all cases will begin from the backwater zone proximal to the reservoir and will extend into higher backwater parts over time.

\section{The magnitude of the reservoir impact on the channel in backwater}

Also the magnitude of effects caused by the reservoir impact within the backwater zone depends on the distance from the reservoir. The closer to the reservoir, the stronger the effect, since the depth of water withdrawing from the reservoir is bigger. The fine sediment supply from the reservoir into the backwater zone also will be larger nearer to the reservoir. Thus, the magnitude of the reservoir impact may be more diversified for steeper, rather than flatter channels, with the same channel length.

\section{The course of changes with time}

Non-uniform frequency and magnitude of the reservoir impact within the backwater zone will cause non-synchronous response and adjustment of individual parts of backwater. The channel adjusts faster to the backwater conditions in its part neighbouring directly on the reservoir. Adjustment will be the longest in the distal part situated farthest away from the reservoir. Thus, one can assume that at the same time we can observe different stages of channel adjustment to backwater conditions depending on the distance from the reservoir. For example, the channel in close proximity of the reservoir can be fully adjusted to backwater conditions, while such changes can be in the initial phase within the distal part of backwater. In order to estimate the significance 
of changes, it is necessary to use a reference reach (see section The application of the model).

\section{The role of vegetation and local conditions}

\section{The role of vegetation}

Vegetation is an important factor affecting channel adjustment within the backwater (Maddock 1966, Xu, Shi 2001). Initially, it increases the erosion resistance of banks and channel forms, thus lowering its susceptibility to short-term changes caused by floods. At the further stages of vegetation succession on the river bed, its banks, and the floodplain, the acceleration of fine sediment deposition rate occurs, thus accelerating channel narrowing and aggradation, and increasing the channel slope locally (Maddock 1966). On the other hand, the presence of vegetation on forms in the channel can also intensify bank erosion in its neighbourhood. However, due to the simultaneous shifting of the thread aside, channel sinuosity increases and transport capacity decreases, and thus erosion surplus is balanced. The impact of vegetation is similar to the increase in bar resistance connected with fine sediment deposition (cf. Xu 2001b). The expansion of vegetation can be considered as its next stage. In such a case, the impact of vegetation intensifies the negative feedback assisting the river in reaching equilibrium. This can explain the decline of fluctuations of the width-depth ratio during adjustment, as described in some studies (e.g. Xu, Shi 1997).

\section{The role of local conditions}

Local conditions can be divided into abiotic and biotic. Abiotic conditions, such as the valley bed relief, bank and channel structure or the type of materials supplied from undercut to the channel, modify the course of adjustment especially in its initial phase of post-dam period. These changes can be visible especially in the short-term approach. Biotic conditions, such as the presence of vegetation and different types of vegetation, also play an important role in the course of adjustment (Gurnell 2013). Also riverine animals, e.g. beavers that contribute to sediment deposition and bed rising on a smaller scale, can have an impact on the channel adjustment course (Pollock et al. 2007).

\section{The river type vs. length of response time and channel adjustment}

It is difficult to determine absolutely the period of response and alluvial channel adjustment to backwater conditions. The course of response and river adjustment to new conditions will depend not only on the trajectory during the pre-dam period, but also on the frequency and magnitude of flood perturbations within the backwater zone, as well the magnitude and frequency of material transport and water flow in the river. The longest adjustment can occur in channels with strengthening sediment deficit (case 1a). In such cases, numerous different trajectories of changes of individual channel parameters within the pre- and post-dam periods occur (Table 2). It can be assumed that the clarity of the moment of beginning response should be most clearly visible in such cases (Fig. 4), but its time can be longer than in the other cases. The magnitude and frequency of material transport is dependent on the grain-size of bed material and on the existing flow conditions that allow its movement. For this reason, the response of gravel bed rivers is slower than that of sand bed rivers (Grant 2012). Channel adjustment to changes in a temperate climate will be longer than in the semi-arid environment (Petts, Gurnell 2005).

\section{The relativity of channel parameter changes}

The model demonstrates that the course of changes of channel parameters observed during the post-dam period can be interpreted as a channel response or adjustment, unless we consider it in the context of previous and actual changes (Fig. 4). For example, in case C (Fig. 4 ), when analyzing the post-dam period only or comparing it to the absolute value of a parameter (e.g. bed-level) at a point directly before the occurrence of a perturbation, it is possible to 
state incorrectly that no change of this parameter occurs in the post-dam period. However, an analysis of an appropriately long trend of this parameter in the reference reach within a specified period of time shows that its course has changed. Similarly, an analysis of a channel parameter in the reference reach during the research period can help indicate the actual tendency of river channel changes.

\section{Implications of the model}

Including the impact of the pre-dam trajectory on the model and demonstrating its effect on the duration and interpretation of the course of channel adjustment trajectory within the post-dam period indicate that such an approach may provide a wider insight into currently observed differences in the course of river adjustment upstream of reservoirs. This also provides an opportunity to predict and better explain the changes specified. Tendencies resulting from pre-dam trajectories may affect the time of channel response and adjustment. They can also modify the course of the processes specified within the post-dam period. For example, the relief and tendencies in the dynamics of channels being in the state of equilibrium between transport capacity and sediment supply, as well as without bank protection (Cases 2) can favour faster adjustment. By contrast, in the case of degraded channels, e.g. by regulation, where erosion tendencies predominate (Cases 1) and bank protection is present, channel adjustment is slower due to hindered bank erosion and energy surplus in such channels, causing for example more frequent scouring of fine sediments coming from the reservoir. However, an increase in the frequency of bank and floodplain flooding, which occurs in backwater, and lower flow velocities in less steep channels can improve the ecological condition of degraded water courses. Taking into account the long-term effects of the reservoir impact on such channels, they can return to the state of equilibrium faster than in the reach beyond backwater. In Cases 3 of overloaded channels with a higher probability of existence of multiple threads, adjustment can be also slower in connection with the time necessary to fill side threads and to develop a single-thread channel, as observed in backwaters (Xu, Shi 1997, Xu 2001a).

The presented analysis also indicates that floods play a reverse role in channel adjustment upstream of a reservoir than in that of downstream reaches. The model shows that floods can slow down channel adjustment in reaches upstream of a reservoir (Table 3, Fig. 2). The channel behaviour downstream of reservoirs is quite reverse (Petts, Gurnell 2005).

\section{The application of the model}

The presented model applies to alluvial rivers. The diversity of adjustments is large, especially in the case of short-term changes. In order for channel parameters to be able to be interpreted as its response to the reservoir construction, research should be carried out parallel in an appropriately chosen reference reach. Only significant differences in the course or extent of changes can be interpreted as river adjustment to the reservoir impact. The application of the model should allow for the following 8 steps:

1. An analysis of cartographic materials, aerial photographs and water and sediment flow information within a pre-dam period longer minimum that the time elapsed from the occurrence of a perturbation, in order to determine the channel structure, dynamics, regulation and hydrotechnical construction currently present within the backwater zone and upstream of it. An analysis of these and other available materials for drainage basin in order to determine the TC to SS tendency.

2. Choosing an appropriate trajectory for the river reach under investigation. Depending on research detail and availability of materials, it can be a general trajectory, e.g. TC $>$ SS or a detailed one, $\mathrm{TC}^{+}>\mathrm{SS}^{-}$

3. Selecting a reference reach and reference period, based on point 1 . The reference reach within the pre-dam period should have a structure and dynamics as close as possible to those of the perturbed reach.

4. An analysis of channel material, bank and floodplain mapping in the reference and examined reaches (e.g. based on Kamykowska et al. 1999), in order to determine the bank cov- 
erage and regulation constructions, as well as the ratio of the actual bank to bed material erosional resistance (e.g. based on Fischenich 2001, pp. 3). An analysis of silt and clay content in channel bar sediments as factors modifying the course and occurrence of floods related to short-term changes, and indicating the present stage of channel adjustment. The backwater reach can be divided and analyzed as smaller sub-reaches in respect of specified features affecting adjustment, e.g. the number of coverings with reservoir waters, channel structure, presence of vegetation etc.

5. Putting forward hypotheses connected with the chosen trajectory of changes in the predam period as well as considering the reservoir operation mode and the results of fieldwork and its effect on the time of response and adjustment (Table 2).

6. An analysis of the course of examined parameters in the test and reference reaches in the pre- and post-dam periods. Setting parameter ranges in the pre- and post-dam periods. A comparison of parameter trends and the extraction of significant differences, in the course of pre- and post-dam periods. A comparison of significant trends to those observed at the same time in the reference reach.

7. Determining the parameters taking part in river response and adjustment.

8. Predicting further channel behaviour.

\section{The limitations and capabilities of the model}

The main limitation of the model is the diversity of resulting channel adjustments within the period of short-term changes. However, the diversity of possibilities is at the same time an advantage of the model and brings a wider insight into channel changes that can occur within a longer period of time. Showing changes in both short- and long-term scales presents the scope of potential changes and their mechanism. It also explains a different way of or lack of noticeable response of river channel parameters to the reservoir construction (cf. Alibert et al. 2011). The use of a reference reach and period proposed in the model can help in conducting research on complex response, especially in water courses subject to strong human influence.

\section{Conclusion}

The investigation of complex response of fluvial systems to perturbations requires a comprehensive approach. Taking into account changes in the time and space context and the relativity of changes proposed in the model is a step in this direction. This may eliminate a part of uncertainties and give a wider insight into the mechanism governing the course of changes in specified channel parameters and mutual interactions of these changes. Backwater reaches can be treated as a specific field laboratory of geomorphological processes that provides plenty of opportunities for such investigations.

\section{References}

Alibert M., Assani A.A., Gratton D., Leroux D., Laurencelle M., 2011. Statistical analysis of the evolution of a semialluvial stream channel upstream from an inversion-type reservoir: The case of the Matawin River (Quebec, Canada). Geomorphology 131: 28-34. DOI: 10.1016/j.geomorph.2011.04.018. ISSN: 0169-555X.

Bhowmik N.G., Adams J.R., Demisse M., 1988. Sedimentation of four reaches of the Mississippi and Illinois Rivers, Sediment Budgets (Proceedings of the Porto Alegre Symposium, December 1988). IAHS Publication 174: 11-19.

Brandt S.A., 2000. Classification of geomorphological effects downstream of dams. Catena 40: 375-401.

Chien N., 1985. Changes in river regime after the construction of upstream reservoirs. Earth Surface Processes and Landforms 10: 143-159. DOI: 10.1002/esp.3290100207.

Chorley R.J., Schumm S.A., Sugden D.E., 1984. Geomorphology. London: Methuen.

Dust D., Wohl E., 2012. Conceptual model for complex river responses using an expanded Lane's relation. Geomorphology 139-140: 109-121. DOI: 10.1016/j.geomorph.2011.10.008.

Evans J.E., Huxley J.M., Vincent R.K., 2007. Upstream Channel Changes Following Dam Construction and Removal Using a GIS/Remote Sensing Approach. Journal of the American Water Resources Association 43: 683-697. DOI: 10.1111/ j.1752-1688.2007.00055.x.

Fischenich C., 2001. Stability Threshold for Stream Restoration Materials. EMRRP Technical Notes Collection (ERDC TN- EMRRR-SR-29), U.S Army Engineer Research and Development Center, Vicksburg, MS. Online: el.erdc.usace.army.mil/elpubs/pdf/sr29.pdf, April 15, 2013. 
Florek E., Florek W., Łęczyński L., 2008. Funkcjonowanie zbiorników zaporowych na Słupi jako czynnik rzeźbotwórczy (Reservoirs of the Słupia River as morphogenetic agents). Landform Analysis 7: 12-22.

Grant G.E., 2012. The Geomorphic Response of Gravel-bed Rivers to Dams: Perspectives and Prospects. In: M. Church, P.M. Biron, A.G. Roy (eds), Gravel Bed Rivers VII: Processes, Tools, Environments. John Wiley \& Sons: 165-181.

Gurnell A., 2013. Plants as river system engineers. Earth Surface Processes and Landforms 39: 4-25. DOI: 10.1002/ esp.3397.

Hey R.D., 1986. River response to inter-basin water transfers: Craig Goch feasibility study. Journal of Hydrology 85: 407-421

Hoey T.B., Sutherland A.J., 1991. Channel morphology and bedload pulses in braided rivers: a laboratory study. Earth Surface Processes and Landforms 16: 447-462. DOI: 10.1002/esp.3290160506.

ICOLD, 1988. World Register of Dams, Update. International Commision on Large Dams, Paris.

ICOLD, 2007. World Register of Dams, Update. International Commision on Large Dams, Paris.

Kamykowska M., Kaszowski L., Krzemień K., 1999. River channel mapping instruction. Key to the river bed description. Prace Geograficzne UJ 104: 9-25.

Kellerhals R., 1982. Effect of river regulation on channel stability. In: Hey R.D., Bathurst J.C., Thorne C.R. (eds), Gravel-bed Rivers. Wiley, Chichester: 685-715.

Klimek K., Łajczak A., Zawilińska L., 1990. Sedimentary environment of the modern Dunajec delta in artifical Lake Rożnów, Carpathian Mts., Poland. Quaestiones Geographicae 11/12: 81-92.

Książek L., 2006. Morfologia koryta rzeki Skawy w zasięgu cofki zbiornika Świnna Poręba (The morphology of the Skawa River bed within back-water reach of Swinna Poręba Reservoir). Infrastruktura i Ekologia Terenów Wiejskich 4/1: 249-267.

Kummu M., Lu X.X., Wang J.J., Varis O., 2010. Basin-wide sediment trapping efficiency of emerging reservoirs along the Mekong. Geomoporphology 119: 181-19. DOI: 10.1016/j.geomorph.2010.03.018.

Lane E.W., 1955. The Importance of Fluvial Morphology in Hydraulic Engineering. American Society of Civil Engineer, Proceedings, 81. Paper 745: 1-17.

Leopold L.B., Bull W.B., 1979. Base level, aggradation and grade. American Philosophical Society, 123: 168-202.

Leopold L.B., Wolman M.G., Miller J.P., 1964. Fluvial Processes in Geomorphology. W.H. Freeman, San Francisco.

Lu Y., Zuo L., Ji R., Liu H., 2010. Deposition and erosion in the fluctuating backwater reach of the Three Gorges Project after upstream reservoir adjustment. International
Journal of Sediment Research 25: 64-80. DOI:10.1016/S10016279(10)60028-5.

Lusby G.C., Hadley R.F., 1967. Deposition behind low dams and barriers in the South-western United States. Journal of Hydrology (NZ) 6: 89-105.

Maddock T. Jr., 1966. Behavior of channel upstream from reservoirs. IAHS Publication 77: 812-823.

Petts G.E., 1979. Complex response of river channel morphology subsequent to reservoir construction. Progress in Physical Geography 3: 329-362. DOI: 10.1177/030913337900300302.

Petts G.E., 1980. Long-term consequences of upstream impoundment. Environmental Conservation 7: 325-332. DOI: 10.1017/S0376892900008183.

Petts G.E., Gurnell A.M., 2005. Dams and geomorphology: Research progress and future directions. Geomorphology 71: 27-47. DOI: 10.1016/j.geomorph.2004.02.015.

Phillips J.D., 2013. Geomorphic responses to changes in stream flows: the flow-channel fitness model. River Research and Applications 29: 1175-1194. DOI: 10.1002/ rra.2602.

Pollock M.M., Beechie T.J., Jordan C.J., 2007. Geomorphic changes upstream of beaver dams in Bridge Creek, an incised stream channel in the interior Columbia River basin, eastern Oregon. Earth Surface Processes and Landforms 32: 1174-1185. DOI: 10.1002/esp.1553.

Schumm S.A., 2005. River Variability and Complexity. Cambridge, New York.

Van Haveren, B.P., Jackson, W.L., Lusby, G.C., 1987. Sediment deposition behind Sheep Creek Barrier Dam, Southern Utah. Journal of Hydrology (NZ) 26: 185-196.

Werrity A., 1997. Short-term changes in channel stability. In: C.R. Thorne, R.D. Hey, M.D. Newson (eds), Applied Fluvial Geomorphology for River Engineering and Management, John Wiley, Chichester: 47-65.

Williams G.P., Wolman M.G., 1984. Downstream effects of dams on alluvial rivers. Geological Survey Professional Paper 1286: 1-83.

Xu J., 1990. Complex response in adjustment of Weihe channel to the construction of the Sanmenxia Reservoir. Zeitschrift für Geomorphologie 34: 233-245.

Xu J., 2001a. Adjustment of mainstream-tributary relation upstream from a reservoir: An example from the Laohahe River, China. Zeitschrift für Geomorphologie 45: 359-372.

Xu J., 2001b. Modified conceptual model for predicting the tendency of alluvial channel adjustment induced by human activities. Chinese Science Bulletin 46: 51-56. DOI:10.1007/BF03187236.

Xu J., Shi C., 1997. The river channel pattern changes as influenced by the floodplain geoecosystem: an example from the Hongshan Reservoir. Zeitschrift für Geomorphologie 41: 97-113. 